\title{
Hypertensive emergency as a complication of brachial plexus block
}

\author{
Sajith Chakithandy, Paul Kelly, James Barron, \\ Department of Anaesthesia, Guy's \& St Thomas' Hospital, London, UK
}

Correspondence to Dr Sajith Chakithandy, drsajithc@yahoo.ca

\section{Summary}

The authors report a case of hypertensive emergency (defined as systolic blood pressure $>180 \mathrm{~mm} \mathrm{Hg}$ and diastolic blood pressure $>110$ $\mathrm{mm} \mathrm{Hg}$ with end organ damage) following brachial plexus blockade in a hypertensive lady with unstable angina. The authors describe blocking of baroreceptor reflexes by the local anaesthetic as a putative mechanism and suggest that this potentially serious complication should be considered when planning this particular anaesthetic technique.

\section{BACKGROUND}

Imaging studies during brachial plexus regional anaesthesia have shown that spread of local anaesthetic is irregular and widespread with no proof for a solid tubular brachial plexus sheath especially in the supraclavicular and interscalene area. ${ }^{1}$ Blockade of the phrenic nerve, causing diaphragmatic paralysis and blockade of sympathetic chain, causing Horner's syndrome and bronchospasm, ${ }^{2}$ are recognised complications. However, reports of inadvertent blockade of nerves innervating carotid and aortic baroreceptors and its consequences are scarce.

\section{CASE PRESENTATION}

A female patient in her 80s weighing $65 \mathrm{~kg}$ was admitted with acute onset weakness of right arm and absence of pulse in radial and ulnar arteries on right side. She was listed for an emergency embolectomy. She had a past history of hypertension, atrial fibrillation (AF) and ischemic heart disease with four coronary artery stents in situ and had a history consistent with unstable angina. She was accepted for anaesthesia as American Society of Anaesthesiologists class 4 Emergency and a supraclavicular brachial plexus block was planned.

On arrival in the anaesthetic room, her heart rate was $63 / \mathrm{min}$ in AF, and blood pressure was $196 / 79 \mathrm{~mm} \mathrm{Hg}$. After intravenous sedation with $1 \mathrm{mg}$ of midazolam, right interscalene brachial plexus block was performed under ultrasound guidance using a nerve stimulator. The procedure was easy to carry out with patient well sedated and calm. $40 \mathrm{ml}$ of $0.25 \%$ bupivacaine was injected. Within $15 \mathrm{~min}$, she became increasingly restless and sweaty and started complaining of central chest pain radiating to the back. Her blood pressure increased to $220 / 110 \mathrm{~mm} \mathrm{Hg}$ on non-invasive blood pressure reading and the heart rate was $90-100 / \mathrm{min}$ in AF. She was treated with intravenous labetalol boluses, diamorphine $2.5 \mathrm{mg}$ was given which settled her chest pain, but she remained hypertensive at 210-230 mm Hg systolic. Her surgery was cancelled, and she was treated with bisoprolol, candesartan and intravenous heparin in the high dependency unit. An emergency
CT angiogram was done which ruled out aortic dissection. The ECG showed ST-T wave flattening in lateral leads with old q waves but no new changes. The troponin at 12 $\mathrm{h}$ was normal. Her blood pressure settled to $145 / 80 \mathrm{~mm} \mathrm{Hg}$ by about $6 \mathrm{~h}$ after the brachial plexus block.

It was decided to re-attempt embolectomy on day 3 of admission. On preoperative examination, her blood pressure remained 200-180 mm Hg systolic and 100-80 mm $\mathrm{Hg}$ diastolic despite treatment with antihypertensive medications. But considering the urgent limb saving nature of the operation and the fact that antihypertensive treatment has been ongoing, she was accepted for the same. Right supraclavicular block under ultrasound guidance with nerve stimulator was done after giving $1.5 \mathrm{mg}$ of intravenous midazolam. She was calm during the procedure, and it was technically easy. Ten millilitre of $2 \%$ lignocaine and $10 \mathrm{ml}$ of $0.5 \%$ chirocaine were given. Fifteen minutes after the block, she became sweaty, confused and complained of central chest pain with backpain. An intraarterial blood pressure monitoring was initiated, and the blood pressure remained consistently high at 230/110 $\mathrm{mm} \mathrm{Hg}$. Her surgery was cancelled and she was further treated with antihypertensives (candesartan and bisoprolol dose was increased). Her blood gas did not show hypoxia or hypercapnia thus ruling out respiratory failure due to phrenic nerve block. The blood pressure settled to $180 / 95 \mathrm{~mm} \mathrm{Hg}$ by $8 \mathrm{~h}$ post block. ECG did not show any new changes, but troponin was increased to 0.1 at $12 \mathrm{~h}$. An echocardiography was performed which showed good systolic function, mild aortic stenosis and mild left ventricular hypertrophy.

\section{DIFFERENTIAL DIAGNOSIS}

Anxiety induced hypertension.

\section{OUTCOME AND FOLLOW-UP}

By day 4, blood flow to the arm was improving on doppler studies, and it was decided to treat her conservatively with intravenous heparin and antihypertensive medication. Her blood pressure remained between 130-100 $\mathrm{mm} \mathrm{Hg}$ systolic and $60-80 \mathrm{~mm} \mathrm{Hg}$ diastolic throughout her stay, and she 


\section{BMJ Case Reports}

regained strength in her right arm with improved pulses. She remained in the hospital another 10 days and was discharged to a nursing home. But by the time of writing up of this report, she had died.

\section{DISCUSSION INCLUDE A VERY BRIEF REVIEW OF SIMI- LAR PUBLISHED CASES}

Hypertension and its clinical implications and treatment have been well described. ${ }^{3}$ Hypertension in the peri operative period has similar implications, but causative factors include anaesthetic and surgical factors in addition to the underlying medical problem. There is one report of hypertension after stellate ganglion block (SGB). ${ }^{4}$ There is no literature concerning hypertension following a supraclavicular block. In addition, there is a case report of hypertension and tachycardia occurring after sectioning of glossoparyngeal nerve, and this was sympathetically mediated responding well to propanolol. ${ }^{5}$ Experimentally, hypertension has been induced in man by unilateral carotid nerve blockade with prilocaine. ${ }^{67}$ This suggests that contra lateral baroreceptor mechanism is incapable of preventing such hypertensive responses. The high blood pressure in this particular case was a reflection of her underlying poorly controlled hypertension which was exacerbated by the local anaesthetic block of baroreceptor mechanism. We suggest that transient blockade of nerves innervating the carotid and aortic baroreceptors resulted in a sustained increase in blood pressure, worsening of angina and myocardial damage. The time of onset of hypertension and its resolution closely follow the timing of regional block thus confirming this hypothesis. This potentially harmful consequence of brachial plexus blockade should be considered when planning supraclavicular regional anaesthetic technique in patients with cardiovascular disease.

\section{Learning points}

- Poorly controlled hypertension is a relative contraindication to supraclavicular brachial plexus block.

- Baroreceptor mechanism mediated cardiovascular instability is to be considered in differential diagnosis of peri-operative hypertensive crisis.

- Hypertensive response during this anaesthetic technique may be an expected side effect.

\section{Competing interests None.}

Patient consent Not obtained.

\section{REFERENCES}

1. Neal JM, Gerancher JC, Hebl JR, et al. Upper extremity regional anaesthesia essentials of our current understanding. Reg Anaesth Pain Med 2009:34:134-70.

2. Thiagarajah S, Lear E, Azar I, et al. Bronchospasm following bracial plexus block. Anesthesiology 1984:61:759-61.

3. The sixth report of the Joint National Committee on Prevention, Detection, Evaluation, and Treatment of High Blood Pressure. Arch Intern Med 1997:157:2413-46.

4. Kimura T, Nishiwaki K, Yokota S, et al. Severe hypertension after stellate ganglion block. Br J Anaesth 2005;94:840-2.

5. Ripley RC, Hollifield JW, Nies AS. Sustained hypertension after section of the glossopharyngeal nerve. Amer J med1977;62:297-302.

6. Kezdi P. Sinoaortic regulatory system: role in pathogenesis of essential and malignant hypertension. Arch Intern Med 1953;91:26

7. Tuckman J, Slater SR, Mendlowitz M. The carotid sinus reflexes. Am Heart J 1965;70:119-35

This pdf has been created automatically from the final edited text and images.

Copyright 2011 BMJ Publishing Group. All rights reserved. For permission to reuse any of this content visit http://group.bmj.com/group/rights-licensing/permissions.

BMJ Case Report Fellows may re-use this article for personal use and teaching without any further permission.

Please cite this article as follows (you will need to access the article online to obtain the date of publication).

Chakithandy S, Kelly P, Barron J. Hypertensive emergency as a complication of brachial plexus block. BMJ Case Reports 2011;10.1136/bcr.01.2011.3754, date of publication

Become a Fellow of BMJ Case Reports today and you can:

- Submit as many cases as you like

Enjoy fast sympathetic peer review and rapid publication of accepted articles

- Access all the published articles

- Re-use any of the published material for personal use and teaching without further permission

For information on Institutional Fellowships contact consortiasales@bmjgroup.com

Visit casereports.bmj.com for more articles like this and to become a Fellow 